\title{
Molecular detection of Babesia vogeli, Ehrlichia canis and Anaplasma platys in a hospital population of dogs clinically diagnosed with hemoparasitosis
}

\section{Deteç̧ão molecular de Babesia vogeli, Ehrlichia canis e Anaplasma platys em uma população hospitalar de cães diagnosticados clinicamente com hemoparasitoses}

\author{
Aline Ticiani Pereira Paschoal ${ }^{1 *}$; Ana Clécia dos Santos Silva ${ }^{1}$; Juliana Correa \\ Bernardes $^{1}$; Eloiza Teles Caldart ${ }^{2}$; Fernanda Pinto-Ferreira²; João Fábio Soares ${ }^{3}$; \\ Aldair Calistro de Matos'; Nathália Rye Moraes ${ }^{5}$; João Luis Garcia²; \\ Odilon Vidotto ${ }^{2}$; Regina Mitsuka-Breganó ${ }^{2}$
}

\section{Highlights:}

The occurrence of hemoparasitosis in dogs from the Londrina region is common.

Molecular techniques should be used as an auxiliary tool for the differential diagnosis of the different etiological agents causing hemoparasitosis in dogs.

Molecular techniques are essential for better investigation and preventive assertiveness etiological agents causing hemoparasitosis in dogs.

\begin{abstract}
There is an increase in tick-borne diseases in dogs in urban and rural areas in Brazil and some of these are of public health importance. Rhipicephalus sanguineus-transmitted hemoparasitoses are the main causes of mortality in dogs. The present study investigated the molecular occurrence of Ehrlichia canis, Babesia vogeli and Anaplasma platys in dogs with clinical sings and hematological abnormalities suggestive of tick-borne diseases. These dogs were seen at a Veterinary Hospital of a Public University between January 2014 and December 2016, and were evaluated through anamnesis, clinical examination and complementary exams. The polymerase chain reaction technique was used to detect the presence of hemoparasites DNA. From the 461 dogs that were tested for B. vogeli, 10.6\% (49/461) were positive, the associated variable was age. Regarding the 730 animals screened for E. canis, 15.1\% (110/730) were positive, and the infection was associated with hematocrit and number of platelets. Relative to the 86 samples evaluated for $A$. platys, $15.1 \%$ (13/86) were positive, and no variable presented statistical significance. From the animals positive for $B$. vogeli, no of these showed positivity by qPCR for Rangelia vitalii. It is concluded that the occurrence of hemoparasitosis in dogs from the Londrina region
\end{abstract}

1 Discentes do Programa de Pós-Graduação em Ciência Animal, Universidade Estadual de Londrina, UEL, Londrina, PR, Brasil. E-mail: ticianipaschoal@gmail.com; anavetufal@gmail.com; bernardescj@gmail.com

2 Profs. Drs., Departamento de Medicina Veterinária Preventiva, UEL, Londrina, PR, Brasil. E-mail: eloizacaldart@uel.br; nandaferreiravet@gmail.com; joaoluisgarcia10@gmail.com; vidotto@uel.br; rbregano@uel.br

${ }^{3}$ Prof. Dr., Departamento de Patologia e Clínica Veterinária, Universidade Federal do Rio Grande do Sul, UFRGS, Porto Alegre, RS, Brasil. E-mail: jfsvet@gmail.com

${ }^{4}$ Técnico Responsável, Laboratório de Moléstias Parasitárias, Departamento de Medicina Veterinária Preventiva, UEL, Londrina, PR, Brasil. E-mail: aldair@uel.br

${ }^{5}$ Médica Veterinária, UEL, Londrina, PR, Brasil. E-mail: nathalia.rye.moraes@gmail.com

*Author for correspondence 
is common. Therefore, it is emphasized that molecular techniques should be used as an auxiliary tool for the differential diagnosis of the different etiological agents causing hemoparasitosis. Additionally, these molecular tools are essential for better investigation and preventive assertiveness because it allows to detect parasite DNA.

Key words: Globular volume. Hemoparasite. PCR.

\section{Resumo}

Há um aumento na ocorrência das doenças transmitidas carrapato em cães em áreas urbanas e rurais no Brasil, algumas, inclusive, são de importância para a saúde pública. As hemoparasitoses transmitidas por Rhipicephalus sanguineus estão entre as principais causas de mortalidade em cães. O presente trabalho teve como objetivo investigar a ocorrência por meio de deteç̧ão molecular de Ehrlichia canis, Babesia vogeli e Anaplasma platys em cães com sinais clínicos e anormalidades hematológicas sugestivas de doenças transmitidas por carrapatos. Esses cães foram atendidos em um hospital veterinário de uma universidade pública entre janeiro de 2014 e dezembro de 2016, onde foram avaliados por anamnese, exame clínico e exames complementares. A técnica de reação em cadeia da polimerase foi utilizada para detectar a presença de hemoparasitas. Dos 461 cães testados para B. vogeli, 10,6\% (49/461) foram positivos, a variável associada foi a idade. Em relação aos 730 animais testados para E. canis, 15,1\% (110/730) foram positivos, e a infecção foi associada ao hematócrito e ao número de plaquetas. Das 86 amostras testadas para $A$. platys, $15,1 \%$ (13/86) foram positivas e nenhuma variável apresentou significância estatística. Dentre os animais positivos para $B$. vogeli, nenhum foi positivo no qPCR para Rangelia vitalii. Conclui-se que a ocorrência de hemoparasitose em cães da região de Londrina é comum. Assim, enfatiza-se que as técnicas moleculares devem ser utilizadas como ferramentas auxiliares para o diagnóstico diferencial dos diferentes agentes etiológicos causadores da hemoparasitose. Além disso, são essenciais para uma melhor investigação e assertividade preventiva, pois permitem detectar o DNA do parasita.

Palavras-chave: Hemoparasita. PCR. Volume globular.

\section{Introduction}

Hemoparasitosis in dogs is among the main causes of morbidity and mortality worldwide, with the Rhipicephalus sanguineus tick being its main vector (Dantas-Torres, 2008). In Brazil, the $R$. sanguineus, or brown dog tick as it is popularly known, transmits through its bite a series of pathogens, such as Babesia, Ehrlichia, Anaplasma and Mycoplasma (Rotondano et al., 2015). The associated clinical manifestations are nonspecific and involve different systems. Clinical signs of fever, lethargy, anorexia, jaundice, and neurological disorders are common clinical manifestations of these diseases; anemia, leukocytosis, leukopenia, and thrombocytopenia can also be observed (Fonseca et al., 2017). Babesia gibsoni and Babesia vogeli are intra-erythrocyte protozoa of the Apicomplexa phylum that cause canine babesiosis (Dantas-Torres \& Figueredo,
2006), with $B$. vogeli being the predominant species in Brazil (A. B. Silva et al., 2012). Babesiosis may present asymptomatic and symptomatic cases, a taxonomic denomination of the parasite is given according to the identified locality (Uilenberg, 2006). Ehrlichia canis, E. chaffeensis, E. ewingii, E. muris and E. ruminantium are the five species that make up the genus Ehrlichia, standing out E. canis is responsible for hemoparasitosis in dogs in Brazil (Azevedo et al., 2011); however, a new genotype was described in cattle and deer in Canada, the Ehrlichia minasensis (Carvalho et al., 2016).

Canine monocytic ehrlichiosis (CME) was first described in Brazil in 1973, in Belo Horizonte, Minas Gerais state (Costa, Batista, Silva, \& Guimarães, 1973). These species are gram-negative, obligate intracellular bacteria of mononuclear cells, such as monocytes and macrophages (Isola, 
Cadioli, \& Nakage, 2010). The clinical condition is non-specific and may present the same abovementioned clinical manifestations (Kataoka, Santana, \& Seki, 2006). The etiological agent responsible for CME is a gram-negative bacterium, Anaplasma platys (Machado, Dagnone, \& Silva, 2010). This hemoparasitosis is characterized by alternating periods of thrombocytopenia associated with the cyclic appearance of the parasite within platelets (Dyachenko, Pantchev, Balzer, Meyersen, \& Straubinger, 2012). Due to this specific characteristic, most dogs do not present the clinical form of the disease (Ribeiro et al., 2017).

Rangelia vitalli is capable of infecting leukocytes and vascular endothelium and is phenotypically similar to babesias (Loretti \& Barros, 2005; Lemos et al., 2017), the vector responsible for its transmission is the tick, Amblyomma aureolatum, reported mainly in the southeastern and southern regions of Brazil (Soares et al., 2015).

The clinical and laboratory diagnosis of these diseases are based on the clinical manifestations that can be associated with hematological changes and the presence of the agent. Evaluation of the peripheral blood smear is the most used routine technique, but this methodology presents low sensitivity and specificity (A. B. Silva et al., 2012). To overcome this problem, the use of molecular techniques, such as the polymerase chain reaction (PCR), should be associated with more reliable results (Witter et al., 2013). The present study aimed to determine the occurrence of Babesia spp., Ehrlichia spp. and Anaplasma spp. relating the presence of the etiological agents in question with possible factors associated with infection and hematological alterations in dogs suspected of hemoparasitosis which had been attended at a veterinary hospital.

\section{Material and Methods}

A retrospective study was performed with 734 dogs, from January 2014 to December 2016, who were evaluated at a veterinary hospital $(\mathrm{VH})$ of Universidade Estadual de Londrina for suspected hemoparasitosis. Samples of blood from these animals were sent to the Veterinary Protozoology Laboratory to identify on one or more agents $(B$. vogeli, E. canis, and A. platys) by using PCR.

Data relative to the breed, age, sex, season of the year in which the animal was tested, and result of the blood count were obtained from the records of these animals. The breeds were classified into two categories, namely: defined breed (DB) and non-defined breed (NDB). Relative to age, the animals were distributed in groups: puppies ( 0 to 12 months), young dogs (13 to 36 months), adults (37 to 96 months) and elderly animals (older than 96 months).

The following hematological parameters were evaluated: red blood cell count, hematocrit percentage, number of leukocytes and number of platelets according to the reference values, 5,5 $8,5 \times 10^{6} \mu \mathrm{L}^{-1}$ for red blood cells, $6-17 \times 10^{3} \mu \mathrm{L}^{-1}$ for leukocytes, 37 - 55\% for hematocrit and 2 - 5 x $10^{5} \mu \mathrm{L}^{-1}$ for platelets (Kaneko, Harvey, \& Bruss, 1997). Were considered with anemia, leukopenia and thrombocytopenia the animals that presented hematological values lower than those mentioned above. The extraction of genomic DNA was performed using commercial QIAmp DNA Blood Mini Kit (Qiagen ${ }^{\mathrm{MT}}$, São Paulo, Brazil) according to the manufacturer's recommendations. In order to control the quality of the DNA extraction, quantification was performed using L-QUANT (Loccus Biotecnologia, Cotia, São Paulo, Brazil), the samples whose extracts had no minimum concentration of $50 \mathrm{ng} / \mu \mathrm{L}$ or purity between 1.6 and 2.0 were submitted to an additional DNNA extraction. Ultrapure water was used as negative controls, blood samples from diseased dogs whose blood smear was positive for visualization of the agents $B$. vogeli or $E$. canis or A. platys were used as positive controls.

For the diagnosis of $B$. vogeli the amplification of a fragment of the $450 \mathrm{bp}$ of $18 \mathrm{~S}$ ribosomal 
RNA gene (RNA) was performed using the primers CAN 626R (5'-GAACTC GAA AAA GCC AAA CGA-3 ') and CAN 172F (5'GTT TAT TAGTTT GAA ACC CGC-3'); for amplification of E. canis, the primers EcavB9-F (5'-CATTATCATTTCAATACGTAACTC-3') and

EcavB9-R

(5'-TTTTGATTTTCTTCTGACATAGTG-3 ') were used to amplify $959 \mathrm{bp}$ of the gene virB9; for A. platys diagnosis, DNA was amplified using primers platys 16S-F (5'-AAGTCGAACGGATTTTTGTC-3') and platys-R (5'-CTCTCCCGACTCTAGTC-3 '), whose target is the gene 16S RNAr (504pb), all of them according to Ribeiro et al. (2017). After amplification, 1.5\% agarose gel electrophoresis was performed with SyBr Safe (Invitrogen ${ }^{\mathrm{TM}}$, California, USA). With the purpose of performing differential diagnosis because the primers CAN 626R and CAN $172 \mathrm{~F}$ can amplify $R$. vitalii, positive samples for $B$. vogeli were subjected to $\mathrm{qPRC}$ to amplification of 1056 bp fragment (GenBank: JF279603) of the hsp70 gene of $R$. vitalii, according to Soares et al. (2018).

The program Epi Info 3.5.4 (CDC, Atlanta, EUA) was used to tabulate the data. The statistical significance between the analyzed variables and the results of the PCR were verified in the program $\mathrm{R}$ 3.3.2 (R Core [R], 2013) by means of simple and multiple logistic regression, considering a level of significance of $5 \%$. To calculate the association between the variables, the crude odds ratio (OR) with a $95 \%$ confidence interval was used.

\section{Results and Discussion}

The frequencies of PCR-positive dogs studied for the different hemoparasites were: $22.5 \%$ $(165 / 734)$ positive for at least one hemoparasite, $10.6 \%$ (49/461) positive for B. vogeli, $15.1 \%$ (110/730) positive for E. canis and 15.1\% (13/86) for $A$. platys. Of the 49 animals positive for $B$. vogeli research, all were negative for $R$. vitalii.
Co-infection was observed in seven animals, one animal presented positivity for E. canis and $A$. platys, and six animals exhibited positivity for $E$. canis and B. vogeli. Positivity for $B$. vogeli was associated with age; hematological alterations (haematocrit, number of erythrocytes and platelets) were the variables associated with infection due to E. canis. No association was identified for A. platys positivity. When considering the results for at least one of the agents analyzed, the associated variables were age, number of erythrocytes, percentage of hematocrit and number of platelets. The results of simple logistic regression are presented in Table 1, multiple logistic regression models were not statistically significant.

Studies conducted in Brazil showed differences in the occurrence of hemoparasites in dogs depending on the region studied, animal population and research methodology, these parasites were detected in $4.9 \%$ to $70.9 \%$ of dogs in reports from South and Central-West regions of the country (Bulla et al., 2004; Dagnone, Autran, Vidotto, Jojima, \& Vidotto, 2003; L. G. F. Santos et al., 2013; Saito et al., 2008; F. Santos et al., 2009; A. B. Silva et al., 2012; Ramos et al., 2009; Ueno et al., 2009). In a study conducted on a population of dogs in the city of Jataizinho, Paraná state, a positivity of $16.4 \%$ E. canis and $19.4 \%$ A. platys was identified using molecular methods (A. B. Silva et al., 2012); similar findings were described in the present study.

The results of the present study showed a reduced occurrence of $B$. vogeli in elderly $(\mathrm{OR}=0.18)$ and adult $(\mathrm{OR}=0.28)$ dogs when compared to puppies; when considering the positivity for at least one hemoparasite, the occurrence in adult dogs $(\mathrm{OR}=0.52)$ was less than that identified in puppies. Similar results were found in a study in the western mesoregion of Maranhão (A. B. Silva et al., 2012). Most likely, the higher rate of infection in puppies is associated with the immaturity of the immune system, which favors the development of the disease (Antunes et al., 2015). 


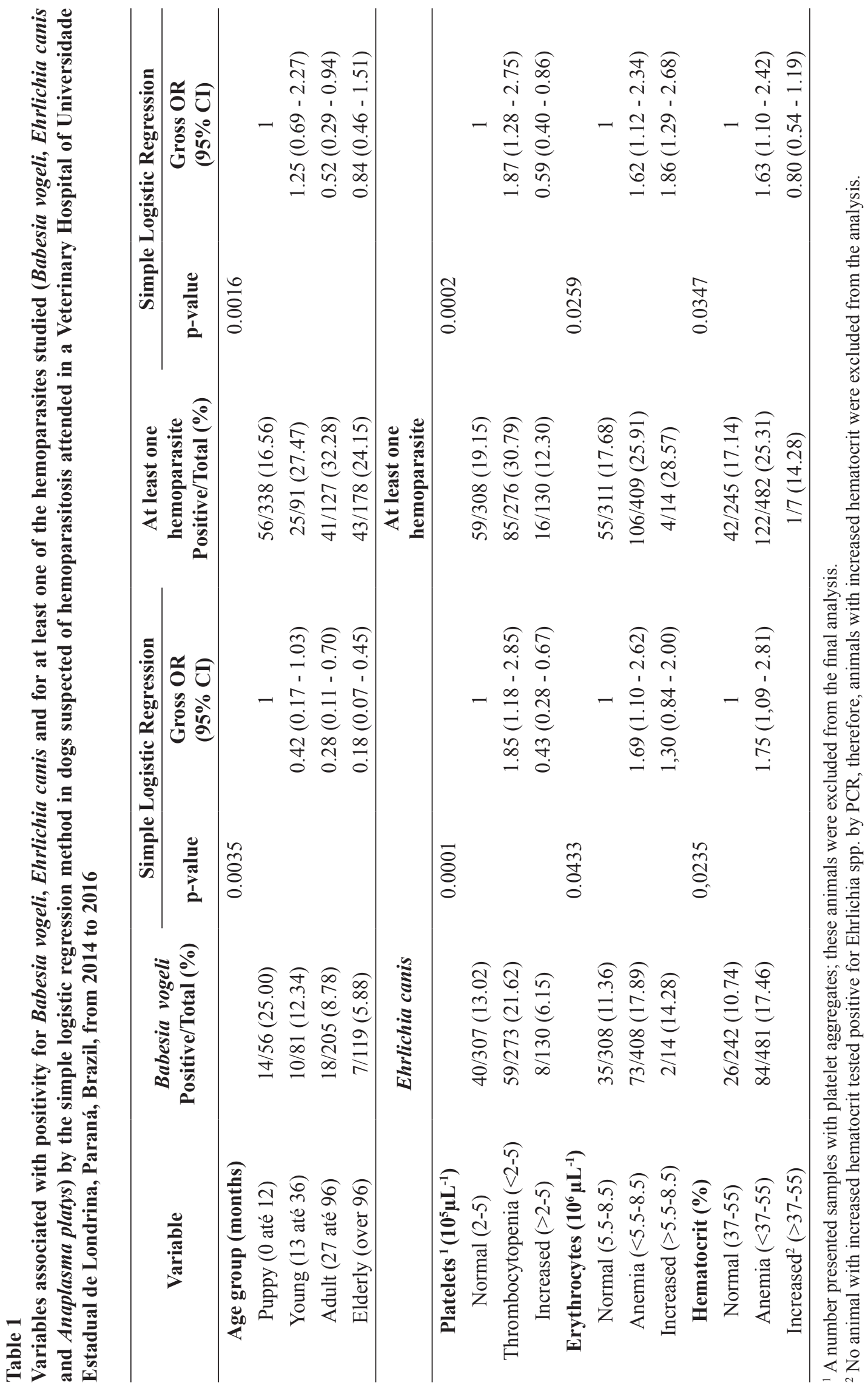

Semina: Ciências Agrárias, Londrina, v. 41, n. 5, suplemento 1, p. 2143-2152, 2020 
Among the hematological alterations observed in dogs form this study, thrombocytopenia, anemia and low hematocrit were considered significant for PCR-positive results for E. canis and for at least one hemoparasite. Similar results were described in a study conducted at a veterinary hospital in São Paulo state (Moya-Araujo et al., 2012). Thrombocytopenia by ehrlichiosis is cyclic; there are times when platelets are low, subnormal or normal, in chronic infection platelet consumption is caused by inflammation in the endothelium, which adds to the destruction by an immune-mediated reaction or splenic sequestration (Harrus, Waner, Bark, Jongejan, \& Cornelissen, 1999; Smith, Miodrag, Huxsoll, \& Baylor 1975; Manoel, 2010). Consequently, a decrease in platelets count is not adequate to confirm the diagnosis of ehrlichiosis in dogs, and further investigation is necessary. In ehrlichiosis, anemia, or a reduction in the number of erythrocytes and, consequently a reduction in the hematocrit, is associated with the inhibition of the bone marrow due to the performance of the monocytic phagocytic system which, when combined with the complement system, suppression of the medullary erythropoiesis (Kakoma et al., 1994; Almosny \& Massard, 2002; Nakaghi, Machado, Costa, André, \& Baldani, 2008; Vieira et al., 2011; Rocha et al., 2016; Maegraith, Gilles, \& Devakul, 1957).

It is important to highlight the presence of a multi-infections due to $E$. canis, B. vogeli and $A$. platys in seven animals. This frequency was low compared to the results obtained in Pernambuco state, where $32 \%$ of the animals presented with a co-infection of E. canis and A. platys (Ramos et al., 2009).

Considering that the 18S rRNA gene shows low polymorphism among Piroplasmida species (Soares et al., 2018), the qPCR was performed to diagnosis $R$. vitalii in the sampled dogs. All animals tested were negative, this result was expected since the A. aureolatum vector is not yet found in Londrina
(Labruna, Guimarães, Pacheco, Pinter, \& Gennari, 2001). However, studies carried out by B. R. Silva et al. (2017), in the metropolitan mesoregions of Curitiba, Central and South Center of Paraná state have identified the A. aureolatum vector in the following cities: Cascavel, Ponta Grossa, Guarapuava, Castro, Carambeí, Campo Largo, Campina Grande do Sul and São José dos Pinhais.

The samples evaluated in the present study were obtained dogs diagnosed clinically, because of this, higher values were expected for the hemoparasites investigated. In Jaboticabal, São Paulo state, $53.3 \%$ of the dogs had tested positive for E. canis by the PCR (Nakaghi et al., 2008). Thus, the low occurrence may be associated with the diagnostic technique used, since detection of the agent in the blood by the PCR is possible if the animal is in the acute phase, in the case of chronicity, this technique may result in false negative result. Therefore, it would be interesting to associate a serological assay with the detection animals in the chronic phase of the disease to improve the sensitivity and specificity of laboratory diagnosis (Witter et al., 2013).

\section{Conclusion}

We can conclude that the Londrina region is endemic for hemoparasitosis in dogs and puppies are more susceptible to infection relative to adults and elderly dogs. Even though hemoparasites cause important hematological alterations in dogs, these changes are not adequate to arrive at a diagnosis. Additionally, molecular techniques are important to confirm a diagnosis and to differentiate the etiological agents involved.

\section{Acknowledgments}

The authors are grateful to the Coordinating Body for the Improvement of Higher Level Personnel (CAPES) for fellowships. 


\section{References}

Almosny, N. R. P., \& Massard, C. L. (2002). Hemoparasitoses em pequenos animais domésticos e como zoonoses. Rio de Janeiro: LF Livros de Veterinária.

Antunes, T. R., Valençoela, R. A., Sorgatto, S., Oliveira, B. B., Godoy, K. C. S., \& Souza, A. I. (2015). Aspectos hematológicos e epidemiológicos de cães naturalmente infectados por hepatozoon sp. no município de Campo Grande, Mato Grosso do Sul, Brasil. Acta Veterinaria Brasilica, 9(3), 234-238. doi: 5385/5829

Azevedo, S. S., Aguiar, D. M., Aquino, S. F., Orlandelli, R. C., Fernandes, A. R. F., \& Uchoa, I. C. (2011). Seroprevalence and risk factors associated to Ehrlichia canis in dogs from the semiarid of Paraíba State, Northeastern Brazil. Brazilian Journal of Veterinary Research and Animal Science, 48(1), 1418. doi: 10.11606/S1413-95962011000100002

Bulla, C., Takahira, R. K., Paparotto, T., Langrafe, L., Paes, P. R., \& Lopes, R. S. (2004). Fase aguda da erliquiose monocítica canina: um estudo retrospectivo de 10 anos. Revista Cientifica de Medicina Veterinária- Pequenos Animais e Animais de Estimação, 2(6), 82-85. doi: 000074\&pid=S0103$8478201000060001100004 \& \operatorname{lng}=\mathrm{en}$

Carvalho, I. T. S., Melo, A. L. T., Freitas, L. C., Verçoza, R. V., Alves, A. S., Costa, J. S.,... Aguiar, D. M. (2016). Minimum infection rate of Ehrlichia minasensis in Rhipicephalus microplus and Amblyomma sculptum ticks in Brazil. Ticks Tick Borne Diseases, 7(5), 849852. doi: 10.1016/j.ttbdis.2016.04.004

Costa, J. O., Batista, J. A., Jr., Silva, M., \& Guimarães, P. M. (1973). Ehrlichia canis infection in dogs in Belo Horizonte, Brazil. Arquivo da Escola de Veterinária da Universidade Federal de Minas Gerais, 25(2), 199-200. doi: 000070\&pid=S19842961200700030000100006\&lng=en

Dagnone, A. S., Autran, H. S. M., Vidotto, M. C., Jojima, F. S., \& Vidotto, O. (2003). Ehrlichiosis in anemic, thrombocytopenic, or tick-infested dogs from a hospital population in south Brazil. Veterinary Parasitology, 117(4), 285-290. doi: 10.1016/j. vetpar.2003.10.001.

Dantas-Torres, F., \& Figueredo, F. L. A. (2006). Canine babesiosis: a Brazilian perspective. Veterinary Parasitology, 141(3), 197-203. doi: 10.1016/j. vetpar.2006.07.030
Dantas-Torres, F. (2008). The brown dog tick, (Latreille, 1806) (Acari: Ixodidae), from taxonomy to control. Rhipicephalus sanguineus. Veterinary Parasitology, 152(3-4), 173-185. doi: 10.1016/j.vetpar.2007. 2. 030

Dyachenko, V., Pantchev, N., Balzer, H. J., Meyersen, A., \& Straubinger, R. K. (2012). First case of Anaplasma platys infection in a dog from Croatia. Parasites \&. Vectores, 5(1), 49. doi: 10.1186/1756-3305-5-49

Fonseca, J. P., Bruhn, F. R. P., Ribeiro, M. J. M., Hirsch, C., Rocha, C. M. B. M., Guedes, E., \& Guimarães, A. (2017). Hematological parameters and seroprevalence of Ehrlichia canis and Babesia vogeli in dogs. Ciência Animal Brasileira, 18, 1-9. doi: 10.1590/1089-6891v18e-36095

Harrus, S., Waner, T., Bark, H., Jongejan, F., \& Cornelissen, A. W. C. A. (1999). Recent advances in determining the pathogenesis of canis monocytic erlichiosis. Journal of Clinical Microbiology, 37(9), 2745-2749. doi: 10.1128/jcm.37.9.2745-2749.1999

Isola, J. G. M. P., Cadioli, F. A., \& Nakage, A. P. (2010). Importância da avaliação hematológica e sorológica (dot-blot ELISA) no diagnóstico de erliquiose em cães. Revista Científica Eletrônica de Medicina Veterinária, 9(18), 1-12. doi: 11449/ 133598

Kakoma, I., Hansen, R. D., Anderson, B. E., Hanley, T. A., Sims, K. G., Liu, L.,... Baek, B. K. (1994). Cultural, molecular, and immunological characterization of etiologic agent for atypical canine ehrlichiosis. Journal of Clinical Microbiology, 32(1), 170-175. doi: $10.1128 / \mathrm{jcm} .32 .1 .170-175.1994$

Kaneko, J., Harvey, J., \& Bruss, M. (1997). Clinal biochemistry of domestic animals. San Diego: Academic Press.

Kataoka, A., Santana, A. E., \& Seki, M. C. (2006). Serum protein profile alterations in dogs naturally infected by Ehrlichia canis. Ars Veterinaria, 22(22), 98-102. doi: 10.15361/2175-0106.2006v22n2p98-102

Labruna, M. B., Guimarães, J. S., Pacheco, R. C., Pinter, A., \& Gennari, S. M. (2001). Prevalence of ticks on dogs from rural areas at northern region of Paraná. Arquivo Brasileiro de Medicina Veterinária e Zootecnia, 53(5), 553-556. doi: 10.1590/S010209352001000500007

Lemos, T. D., Toma, H. K., Assad, R. Q., Silva, A. V., Corrêa, R. G. B., \& Almosny, N. R. P. (2017). Clinical and hematological evaluations of Rangelia vitalii naturally infected dogs in southeasyern Brazil. Revista Brasileira de Parasitologia Veterinária, 26(3), 307-313. doi: 10.1590/s1984-29612017040 
Loretti, A. P., \& Barros, S. S. (2005). Hemorrhagic disease in dogs infected with an unclassified intraendothelial piroplasm in southern Brazil. Veterinary Parasitology, 134(3-4), 193-213. doi: $10.1016 /$ j.vetpar.2005.07.011

Machado, G. P., Dagnone, A. S., \& Silva, B. F. (2010). Anaplasmose Trombocítica Canina - uma breve revisão. Revista Científica Eletrônica de Medicina Veterinária, 8(15), 1-12. doi: 8J0itKMfE0OXrcN_ 2013-6-25-16-43-23.pdf

Maegraith, B., Gilles, H. M., \& Devakul, K. (1957). Pathological processes in Babesia canis infections. Zeitschrift fur Tropenmedizin und Parasitologie, 8(4), 485-514. doi: 13531539

Manoel, C. S. (2010). Alterações clínicas, hematológicas e sorológicas de cães infectado por Erlichia canis. Dissertação de mestrado, Universidade de São Paulo, São Paulo, Brasil.

Moya-Araujo, C. F., Batista, G. A. H., Ribeiro, M. G., Sturion, T. T., Araújo, D. C., \& Araújo, J. P., Jr. (2012). Correlação dos achados clínicos e hematológicos com diagnóstico definitivo de erliquiose canina por meio de PCR. Semina: Ciências Agrárias, 33(6), 23012306. doi: 10.5433/1679-0359.2012v33n6p2301

Nakaghi, A. C. H., Machado, R. Z., Costa, M. T., André, M. R., \& Baldani, C. D. (2008). Canine Ehrlichiosis: clinical, hematological, serological and molecular aspects. Ciência Rural, 38(3), 766-770. doi: 10.1590/ S0103-84782008000300027

R Core (2013). A language and environment for statistical computing. $R$ Foundation for Statistical Computing. Vienna, Austria. Available from http:// www. R-project.org

Ramos, C. A. N., Ramos, R. A. N., Araújo, F. R., Guedes, D. S., Souza, I. I. F., Ono, T. M.,... Alves, L. C. (2009). Comparação de nested-PCR com o diagnóstico direto na detecção de Ehrlichia canis e Anaplasma platys em cães. Revista Brasileira de Parasitologia, 18(1), 58-62. doi: 10.4322/rbpv. 018e1011

Ribeiro, C. M., Matos, A. C., Azzolini, T., Bones, E. R., Wasnieski, E. A., Richini-Pereira, V. B.,... Vidotto, O. (2017). Molecular epidemiology of Anaplasma platys, Ehrlichia canis and Babesia vogeli in stray dogs in Paraná, Brazil. Pesquisa Veterinária Brasileira, 37(2), 129-136. doi: 10.1590/S0100736X2017000200006

Rocha, J. M., Carvalho, F. S., Cedraz, H., Santiago, R., Carlos, R., Luíz, P.,... Arias, A. (2016). Diagnóstico molecular de Ehrlichia canis em cães com alterações clínicas, hematológicas e bioquímicas, no município de Ilhéus, Bahia. Revista Brasileira Medicina Veterinária, 38(4), 345-352. doi: BJVM/ article/ view/75/30

Rotondano, T. E. F., Almeida, H. K. A., Krawzak, F. S., Santana, V. L., Vidal, I. F., Labruna, M. B.,... Melo, M. A. (2015). Survey of Ehrlichia canis, Babesia spp. and Hepatozoon spp. in dogs from a semiarid region of Brazil. Revista Brasileira de Parasitologia Veterinária, 24(1), 52-58. doi: 10.1590/S198429612015011

Saito, T. B., Cunha, N. A., Fº, Pacheco, R. C., Ferreira, F., Pappen, F. G., Farias, N. A.,... Labruna, M. B. (2008). Canine Infectionby Rickettsiae and Ehrlichiae in Southern Brazil. The American Journal of Tropical Medicine and Hygiene, 79(1), 102-108. doi: 14761645/79/1/102.pdf?expires=1563888702\&id $=\mathrm{id} \&$ accname $=$ guest $\&$ checksum $=$ E3BB50BB7AB3 8B5F1EBF00AD59EEA031

Santos, F., Coppede, J. S., Pereira, A. L., Oliveira, L. P., Roberto, P. G., Benedetti, R. B.,... Marins, M. (2009). Molecular evaluation of the incidence of Ehrlichia canis, Anaplasma platys and Babesia spp. in dogs from Ribeirão Preto, Brazil. The Veterinary Journal, 179(1), 145-148. doi: 10.1016/j.tvjl. 2007. 08.017

Santos, L. G. F., Melo, A. L. T., Moraes, J., Fº, Witter, R., Labruna, M. B., \& Aguiar, D. M. (2013). Molecular detection of Ehrlichia canisin dogs from the Pantanal of Mato Grosso State, Brazil. Revista Brasileira de Parasitologia Veterinária, 22(1), 114-118. doi: 10.1590/S1984-29612013005000013

Silva, A. B., Costa, A. P., Sá, J. C., Costa, F. B., Santos, A. C. G., \& Guerra, R. M. S. N. de C. (2012). Detecção molecular de Babesia canis vogeli em cães e em Rhipicephalus sanguineus na mesorregião do oeste maranhense, nordeste brasileiro. Ciência Animal Brasileira, 13(3), 388-395. doi: 10.5216/cab. v13i3.18439

Silva, B. R., Garcia, M. V., Rodrigues, V. S., Andreotti, R., \& Dittrich, R. L. (2017). Ixododae fauna of domestic dogs in Paraná, southern Brazil. Revista Brasileira de Parasitologia Veterinária, 26(3), 375377. doi: 10.1590/s1984-29612017021

Smith, R. D., Miodrag, R., Huxsoll, D. L., \& Baylor, R. (1975). Platelet kitnetcs in canine erlichiosis: evidence for increased platelet destruction as the cause of thrombocytopenia. Infection and Immunuty, 11(6), 1216-1221. doi: 10.1128/IAI.11.6.12161221.1975 
Soares, J. F., Carvalho, L., Maya, L., Dutra, F., Venzal, J. M., \& Labruna, M. B. (2015). Molecular detection of Rangelia vitalii in domestic dogs from Uruguay. Veterinary Parasitology, 210(1-2), 98-101. doi: 10. 1016/j.vetpar.2015.03.013

Soares, J. F., Costa, F. B., Soares, A. G., Silva, A.S., França, R.T., Taniwaki, S. A.,... Labruna, M. B. (2018). Evaluation of the vector competence of six ixodid tick species for Rangelia vitalii (Apicomplexa, Piroplasmorida), the agent of canine rangeliosis. Ticks and Tick-borne Diseases, 5(9), 1221-1234. doi: 10.1016/j.ttbdis.2018.05.004

Ueno, T. E., Aguiar, D. M., Pacheco, R. C., Richtzenhain, L. J., Ribeiro, M. G., Paes, A. C.,... Labruna, M. B. (2009). Ehrlichia canis em cães atendidos em hospital veterinário de Botucatu, Estado de São Paulo, Brasil. Revista Brasileira de Parasitologia Veterinária, 18(3), 57-61. doi: 10.4322/rbpv.01803010
Uilenberg, G. (2006). Babesia a historical overview. Revista Brasileira de Parasitologia Veterinária, 138(1-2), 3-10. doi: 10.1016/j.vetpar.2006.01.035

Vieira, R. F. C., Biondo, A. W., Guimarães, A. M. S., Santos, A. P., Santos, R. P., Dutra, L. H.,... Vidotto, O. (2011). Ehrlichiosis in Brazil. Revista Brasileira de Parasitologia Veterinária, 20(1), 1-12. doi: 10. 1590/S1984-29612011000100002

Witter, R., Vecchi, S. N., Pacheco, T. D. A., Melo, A. L. T., Borsa, A., Sinkoc, A. L.,... Aguiar, D. M. (2013). Prevalência da erliquiose monocítica canina e anaplasmose trombocítica em cães suspeitos de hemoparasitose em Cuiabá, Mato Grosso. Semina: Ciências Agrárias; 34(6Sup12), 3811-3822. doi: 10. 5433/1679-0359.2013v34n6Supl2p3811 
